\title{
Proposed Strategy to Establish "Promising" Athletics Schools in Jordan
}

\author{
Dr. Raed.M.Ragad \\ Albalqa Applied University, Jordan \\ Dr. Hisham Ali ALdmour \\ Dean of the Al Karak University College \\ E-mail: mohammad_n_k_s@yahoo.com \\ Dr. Samer Nahar AL-Soub \\ Mutah University, Mutah, Jordan \\ Taha Mohamad Tarawneh \\ Albalqa Applied University, Jordan
}

Accepted: March 17, 2013 Published: April 30, 2013

Doi:10.5296/jsr.v4i1.3432

URL: http://dx.doi.org/10.5296/jsr.v4i1.3432

\begin{abstract}
This study aimed to identify the strategy proposed to establish a "promising" Athletics schools in Jordan, researchers used descriptive approach approach, the sample of the study consisted of (104) randomly selected persons representing coaches, referees, and managers, after statistical analysis the results of the study found that the degree of the strategy implementation in the areas of (selection of "promising" foundations, objectives, curriculum and special programs, coaches qualifying, facilities and human resources, evaluation) appeared in a high degree. While constraints area appeared in a high degree from the point of view of the study sample. Results showed a statistically differences depending on the experience variable for the favor of administrators in (objectives, curriculum and special programs, evaluation) areas in comparison with the coaches and referees, in (fundamentals of selection, potential and human resources, qualifying of trainers, constraints) areas for the favor of coach compared with practical experiences and referees. The results indicated that there were no significant differences in the study variables depending on the variable (gender, qualifications, and experience). The study recommends that Jordan Athletics Federation adopt this strategy to establish "promising" schools in athletics, and address the constraints that limit the "promising" schools project.
\end{abstract}

Keywords:-Organization, management, athletics, promising, schools 


\section{Introduction to the study and its significance:}

The organizational and administrative environment in which institutions operates in considered a fundamental and helping factor in its development and development to gain a continuous achievable objectives, which secures the a good ground for the work of the institutions, and that the strategic management is a dynamic system that complete the management development methods and aims to involved the mangers and subordinate in setting goals and program, and determine the level of work performance, motivation and evaluation, the recent trends in institutions management indicate that the preparation of organized strategies based on scientifically codified foundations in order to manage the work in a way that ensures the success of the enterprise to reach the level of real accomplishment, Sports institutions organize its work in such a way as to ensure its competitiveness through constructive planning in preparing its strategies to ensure institutional work dynamic as a comprehensive method in thinking, management and decision-making in a way to ensure the interest of the sports institution, (Abu Halima, 2004), (Al-Khatib, 2003).

Strategic planning contributes in improving the work of the Foundation, organize the ideas, and define and achieve objectives, commensurate with the requirements of the environment and their members in accessing to an advanced level, which puts the State in the field of competition with others, (Al Najjar, 2001), studies indicate that the term strategy aimed at organizing the ideas in a procedural plans and program with a view to changing the system components according to the philosophy, objectives and directions of the system, and that the strategy pattern of decisions related to the future of the organization including goals and accomplishments to be achieved by all means and possibilities, And study the reality of the surrounding of the work which is based on procedural and organized ideas in a scientific manner to keep in pace with the future developments, consistent with the philosophy and trends of the country, (Aboee, 2006), (Robsan, 1997).

The world is moving towards strategic planning to develop its political educational, sport and economic institutions, to the benefit of their peoples, as that strategic planning is an important factor and provide a clear progress compared to the countries that built its institutions randomly, and it's a process to define the organization's mission, goals and strategies to secure resources to contribute to the achievement of the goals of the institution, (Besanko, 2000), (Glaister, 1999).

The strategic planning is process to determine how the organization access its goals, and the extent of the use, update and application of strategies is reflected on the of sports progress, the better the level of implementation is reflected in the development level of the sport institution (Al-Rakad, 2011), and there are grounds to build strategies, most notably the weakness and errors of institutional performance, the increased competition, the lack of human resources, the continuous change in administrations, the inability of the Organization to keep pace with rapid developments and the poor achievements compared with modern strategies that achieve growth for the enterprise or the country, (Al-Galibi, 2007), (Aboee 
‘2006) ،(Bonn, 1995).

"promising" role can be seen in the continuation of athletics events, understanding its core, progress, prosperity and spread nationwide, so there must be a structure to organize "promising" schools in terms of objectives, qualifying trainers, providing money, selection and evaluation methods, in order to reach advanced levels of achievement.

And "promising" person is the individual who has the ability and the natural willingness to be creative in an art or activity is, in another context, the term "promising" (or talented) describes an individual whose performance indicates a distinct readiness in some areas that need special abilities whether sports, medical, or engineering (Hussain, 2007), (Issa, Radwan, 2007) indicate that sports are essential and physical skills that must be acquired by the learner ("promising") at an early age, and this is only achieved through a strategy built on clear scientific foundations, "promising" individual attend special schools in athletics at an early age, a group of researchers (Kamel, 2009), (Kriemadis, 1997), (Joel, 2003) that the most "promising" individual attend athletics school at the age of 8 years which is the perfect age to learn the athletics events, providing them with the necessary physical abilities for this sport, develop talents and provided him with early experiences to achieve higher accomplishment. The researcher makes a survey of previous studies and the theoretical literature in the study field and reached the following similar studies:

- ISSA, and Radwan (2009), conducted a study aimed to identify the reality and constraints on strategic planning of sports federations: a comparative study between Jordan and Yemen, the researchers used the descriptive approach, the sample of the study consisted of (107) intentional selected members representing the chairpersons and members of the Olympic sports federations, (55) from Jordan and (52) from Yemen, after the statistical analysis the statistical results indicated that strategic planning in Jordanian sports federations very high compared with strategic planning in Yemen Country sports federations which were moderate, Strategic planning constraints were moderate in both countries, also there are differences in all areas of study depending on the country variable and for the sporting federations favor.

- Kamel (2009), conducted an analytical theoretical study it is goal is to study the new strategies for training planning of beginners in the sport of swimming, and after review of digital worlds swimmers compared with the numbers of swimmers on Egypt revealed that there is a difference in large numbers prompting the researcher to study new strategies to train swimming beginners and it was established in the three main axes, sport selection strategies, physiological training strategies, and technical performance analysis strategies in swimming, the researcher emphasized the need to use the previous strategies in preparing swimmers on Egypt.

- Al-Zogbee (2007) conducted a study aimed at identifying strategic sport building in the Al-Balqa University from the perspective of students, teachers and workers in the field of sports, the researcher used the descriptive approach method, the sample of the study consisted of (318) worker in the University. The results of the study indicated that from the point of 


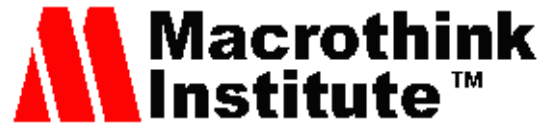

view of students, professors and worker in the sports activity towards building a strategy for sport for everybody with a very high level in all areas.

- Taha (2007) conducted a study to identify the strategic development of volleyball, and the researcher used the descriptive approach method, the sample of the study consisted of (288) society member representing (94) people of expert and opinion, (44) administrators, (25)trainers, (22)referees and (103) players, and the study found that the game needed a strategy to manage its affairs and the re- construction of the Jordanian volleyball Federation, the study also found the lack of schools for junior volleyball, weak material support from the IOC, and the material income of the Union.

- S'adah(2006) conducted a study aimed at identifying strategic thinking and decision-making styles and their relationship in Jordanian sports federations, researchers used the descriptive approach, the sample of the study consisted of (182) leaders in Jordan and Olympic sports federations, the study found weakness in strategic thinking patterns in sports leadership in Jordan and that Jordan's sports leadership uses multiple styles in the decision making, the most important one is the participatory style, and the results of the study indicate that there is a positive relationship between the level of strategic thinking and decision taking on one hand and the experience, qualifications and job on the other hand, and that there is a positive relationship between strategic thinking and decision-making.

- Keeshtah (2004), conducted a study aimed to identify the strategic planning in the Palestinian sports federations for the tournament, the researcher used the descriptive approach, the sample of the study consisted of 50 members, representing the heads members of management and boards of Palestinian sports federations and after statistical analysis the study reached that the Palestinian sports federations targets needs alteration after every time period, and also there are no program to raise the individual and collective level of game, and in accepting administrators the focus is set on the experience and not the qualifications, and there are no bases applied by the unions in selecting its players, and there isn't enough budget in the unions in implementing its program.

- Marwa (2000) held a study aimed to identify a strategy for increasing the number of practitioners of volleyball in the area of Helwan, Egypt, the researcher used the descriptive approach approach, the sample of the study consisted of (159) members representing the General sports administration, and management in the area of Helwan, coaches and Board members, the study reach a structural building represented in setting goals, identifying human and material potential, policies, procedures and the methods of evaluation and observation to help in spreading volleyball game in Helwan.

- (Hunt, 2000), the study aimed to identify the British Government's sports strategy decisions required to implement, the study illustrated the urgent need for the British Government to develop a comprehensive national strategy for all regions to encourage people to practice sports activities.

- The Al Magreebe (1999), conducted a study aimed at identifying the ways of caring for "promising" sports elements in Egypt, the researcher used the descriptive approach, the sample of the study consisted of (394) sports expert, the study found that there is a set of constraints facing "promising" sports care, such as coaches, leaders, evaluation, regulations and instructions, it came in a small amount according to the answers of the study sample. 
- (Smyth, 1998), conducted a study aimed at developing the strategy in the middle school sports institutes in Canada, the researchers used the descriptive approach, the sample of the study consisted of (320)member, the study found the necessity in building general strategy organizational structure, long-term plans to raise the level of sport in Canada.

\section{Comment on previous studies}

Noted by the similar previous studies in the subject of the study that the researcher benefited from choosing a study approach, this study was characterized by previous studies that it looked at the proposal of strategy to establish "promising" schools in athletics, and within science researchers knowledge they didn't found studies looking at establishing "promising" Athletics schools, and characterized in terms of building measurement tool that differs from similar studies axes, also it was the only study that addressed the establishment of schools for "promising" individuals in Jordan since Jordan Athletics Federation in Jordan Athletics.

\section{Importance of the study}

Strategic planning is important in determining the work vision systematically that ensures success and vision for the future, in case of strategic building the past of enterprise's must be studied and stand on the positive and negative points during its life, and after reviewing the found strategies in the Jordan Olympic Committee specifically Jordan Athletics Federation the researcher sees that the importance of the study is that the strategy help Jordan Athletics Federation in organizing the work of "promising" schools for long stages and that strategy works to identify the future vision of "promising", as well as spreading the Athletics events in all regions, and Identify mechanisms for "promising" evaluation in scientific and appropriate methods to produce the best, and the improvement of the strategy develop the administrative work of the union .

\section{The problem of the study}

The lack of strategy cause the negativity of work, especially when the vision is not clear, and work in the organization individually done and thoughts are random and unplanned, the "promising" is considered on the tracks of the Jordan Athletics Federation project, and its goals is to make the Athletics events the most popular and practiced events in Jordan, but the project stalled over management course and the reason is the absence of a clear strategy.

Jordanian Athletics sports live in difficult conditions in all its events since its foundation in (1961), specialists in the field of sports interest understand that taking care of "promising" is the fruit that they reaped from schools to spread the game and build teams, while these projects are stalled because of the lack of a clear strategy in its management, and this is applicable in the Jordan Athletics Federation in the absence of "promising" strategy.

The researcher didn't find any strategy to help him in implementing the "promising" project 


\section{Macrothink}

after looking through archive of the Jordan Athletics, however, and he found that there is a random work done in unorganized way in implementing the work of the federation, therefore that researchers suggested building a strategy to establish "promising" Athletics schools in Jordan.

\section{The objectives of the study}

The study aims to identify:

- The reality of the proposed strategy to establish "promising" Athletics in Jordan.

- Differences in strategic reality proposed by the study variables (gender, qualifications, expertise and years of experience).

\section{Study questions:}

- What is the reality of the proposed strategy to establish Athletics "promising" schools in Jordan?

- Are there statically differences in the proposed strategy depending on study variables (gender, qualifications, expertise and years of experience)?

\section{Study terms:}

Strategy: is a management style served the Foundation in organizing its structural work within scientific rules and basis for determining future vision according to the philosophy and goals of the institution, (Keeshtah, 2004).

The "promising" schools: centers equipped to train individuals for physical, technical and plan characteristics for athletics events, characterized by widespread in all regions with the aim of spreading the game. *

"Promising": are individuals selected in a scientific bases within the specifications for the Athletics events, in order to train and prepare them to gain knowledge and skills in athletics*.

\section{Study limitations:-}

Human domain: trainers, referees and administrators in the Jordan Athletics Federation.

Spatial domain: Jordan Athletics Federation.

Time: this study was conducted in 2011/2012.

\section{Study procedures:-}

Study approach: researchers used descriptive approach, survey method, as it is relevance to this study

Study community: study community consisted of the Jordanian Federation of athletics

\footnotetext{
Procedural personally identifiable
} 
workers (coaches, referees, administrators), for the second cycle (2008 - 2012), (198) coach referee and administrative distributed as shown in table 1.

Table (1)Distribution of study community

\begin{tabular}{|l|l|l|l|l|}
\hline Variables & male & female & $\begin{array}{l}\text { total per } \\
\text { variable }\end{array}$ & Percentage \% \\
\hline Athletics coaches & 45 & 10 & 55 & $\% 27.8$ \\
\hline Referees of Athletics & 36 & 13 & 49 & $\% 24.7$ \\
\hline Administrators & 60 & 34 & 94 & $\% 47.5$ \\
\hline Total & 141 & 57 & 198 & $\% 100$ \\
\hline
\end{tabular}

Sample of the study: the sample consisted of practical experiences individuals in athletics (coaches, referees, and administrators), (104) persons representing (52\%) of the study community, were selected intentional, distributed as shown in table 2.

Table (2)The distribution of the sample members according to the practical experience

\begin{tabular}{|l|l|l|l|l|}
\hline Variables & male & female & $\begin{array}{l}\text { total per } \\
\text { variable }\end{array}$ & Percentage \% \\
\hline Athletics coaches & 33 & 5 & 38 & $\% 36.5$ \\
\hline Referees of Athletics & 25 & 3 & 28 & $\% 26.9$ \\
\hline Administrators & 22 & 16 & 38 & $\% 36.5$ \\
\hline Total & 80 & 24 & 104 & $\% 100$ \\
\hline
\end{tabular}

Table (3)Distribution of sample members depending on the years of experience variable

\begin{tabular}{|l|l|l|l|l|}
\hline Variables & male & female & $\begin{array}{l}\text { total per } \\
\text { variable }\end{array}$ & Percentage \% \\
\hline More than years & 27 & 6 & 33 & $\% 31.7$ \\
\hline 3-5 years & 33 & 7 & 40 & $\% 38.5$ \\
\hline Less than 3 years & 20 & 11 & 31 & $\% 29.8$ \\
\hline Total & 80 & 24 & 104 & $\% 100$ \\
\hline
\end{tabular}

Table (4)Distribution of sample members according to the degree variable

\begin{tabular}{|l|l|l|l|l|}
\hline Variables & male & female & $\begin{array}{l}\text { total per } \\
\text { variable }\end{array}$ & Percentage \% \\
\hline Higher education & 14 & 4 & 18 & $\% 17.3$ \\
\hline BA & 15 & 13 & 28 & $\% 26.9$ \\
\hline Diploma & 51 & 7 & 58 & $\% 55.8$ \\
\hline Total & 80 & 24 & 104 & $\% 100$ \\
\hline
\end{tabular}


Study tools: researchers used the following tools to collect data:

First: scientific references:

The researcher went back to scientific references of (AlGalbi, 2007), (Keeshtah, 2004). And refer to the scientific studies and research of (ISSA, 2007), (Taylor, 2007), (Kamel, 2009), as well as referring to the official documents and records of the Jordanian Federation of Athletics 2011.

Second: personal interviews:-

Researchers conducted interviews with specialists in physical education and the Jordan Athletics Federation and they fill the documents from the Jordan athletics archive, appendix (2).

Third: preparation of the initial phase of the questionnaire, the appendix (3). Final phase of the questionnaire, appendix (4).

Fourth: researchers used the pentatonic scale to answer the questionnaire paragraphs, and answers were given (5) degrees, distributed as follows:

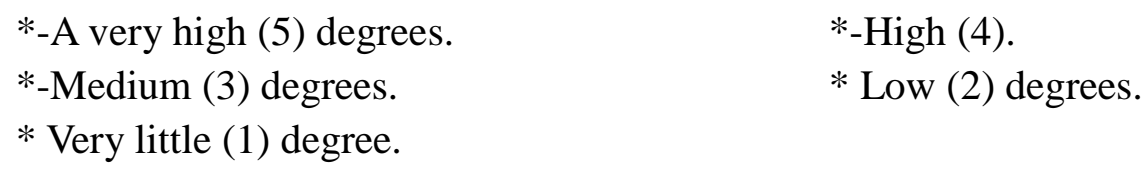

Fifth: interpretation of results based on the percentage of the appreciation of the reality of the proposed strategy to establish "promising" schools for athletics events, the researchers adopted scientific references (Taha, 2007; ISSA 2009) in the percentages distribution on the ladder answers:-

$*_{-}(85 \%)$ and above a very high score. $\quad *_{-}(84 \%-70 \%)$ High score.

$*_{-}(69 \%-55 \%)$ Moderate. $\quad *_{-}(54 \%-40 \%)$ a little degrees.

* (39\%-below) very little.

\section{The scientific parameters of the study:-}

Content validity: the researchers distributed the questionnaire to a group of (5) arbitrators with experience and education in the field of physical education and athletics, appendix(1), to express an opinion on each of the areas the questionnaire was developed to measure according to which the evaluation of the proposed strategy for the "promising" schools appendix (3), and after examining the views and observations of the arbitrators it was found that there is consensus on the validity and relevance of domains, there were some observations on some paragraphs related to deletion and addition as shown in appendix (4).

\section{Tool stability:}


First:-reliability coefficient was calculated for the questionnaire (Test-Retest) on a (12) sample members of community of the study population with two weeks difference between the first and second application they were excluded from the original study sample as shown in table (5).

Table (5)Reliability coefficients for the proposed strategic areas for athletics

\begin{tabular}{|l|l|}
\hline Areas & Reliability coefficients \\
\hline The selection grounds & 0.79 \\
\hline Goals & 0.81 \\
\hline Curriculum and special programs & 0.85 \\
\hline Coaches qualification & 0.89 \\
\hline Potential and human resources & 0.83 \\
\hline Constraints & 0.87 \\
\hline evaluation of "promising" schools & 0.81 \\
\hline
\end{tabular}

Table (5) shows the values of the coefficients of reliability test method and its application, and it was high and values were limited between (0.79-0.89).

Second. The reliability coefficients were calculated by Cronbach's alpha of internal consistency and table (6) illustrates this.

Table (6)Reliability coefficients in a Cronbach's alpha of internal consistency between areas

\begin{tabular}{|l|l|}
\hline Areas & Reliability coefficients \\
\hline The selection grounds & 0.85 \\
\hline Goals & 0.82 \\
\hline Curriculum and special programs & 0.84 \\
\hline Coaches qualification & 0.90 \\
\hline Potential and human resources & 0.89 \\
\hline Constraints & 0.87 \\
\hline evaluation of "promising" schools & 0.86 \\
\hline
\end{tabular}

Table (6) shows the reliability values according to Cronbach's alpha coefficients and was high and limited to values between (0.82-0.90).

\section{Statistical treatment:}

The researchers used a statistical analysis system (SPSS).

- Arithmetic mean, standard deviation, percentage.

- one-sample t-test 


\section{MlMacrothink}

- one-way anova

\section{Results and discussion:}

Question 1: what is the reality of the proposed strategy to establish "promising" schools for athletics in Jordan? Arithmetic mean, standard deviation and the percentages were extracted as shown in table (7).

Table (7)The arithmetic mean, standard deviation and percentage according to the area of "promising" selection foundations

\begin{tabular}{|l|l|l|l|l|}
\hline No. & "promising" selection foundations area & $\begin{array}{l}\text { arithmetic } \\
\text { mean }\end{array}$ & $\begin{array}{l}\text { standard } \\
\text { deviation }\end{array}$ & percentage \\
\hline 1 & desire talented in athletics practice & 4.12 & 0.87 & $\% 82.4$ \\
\hline 2 & physical measurements & 4.39 & 1.02 & $\% 87.8$ \\
\hline 3 & Select physical and skill tests & 4.58 & 0.59 & $\% 91.6$ \\
\hline 4 & Select physiological tests & 3.00 & 0.86 & $\% 60$ \\
\hline 5 & promising" medical disclosure & 4.15 & 0.68 & $\% 83$ \\
\hline 6 & the selection Committee & 3.43 & 0.48 & $\% 68.6$ \\
\hline
\end{tabular}

Highest degree (30)

lowest degree (6) $n=104$

Table 7 shows the statistical results of the foundations of "promising" selection, the estimation in general was high $(78.8 \%)$. And the degree of estimation was limited between very high, high and medium, and that the most estimated paragraphs from the point of view of the study sample was paragraph (3), (Select physical and skill tests) with (91.6\%) percentage which is very high estimation, followed by paragraph (2), (physical measurements), with (87.8\%) percentage which is very high estimation, and the least recognition of paragraphs was paragraphs (4) (select physiological tests) with $(60 \%)$ percentage which is considered a moderate estimation, and that the attention to physiological aspects at this stage came medium. Researchers explains these answers that in selecting the most "promising" the focus must be on physical abilities followed by performance, and then physical specifications as an indicator of choosing bases. The results of this study are consistent with (Kamel, 2009), (Keeshtah, 2004) studies, to take into consideration the scientific foundation on choosing the most "promising", as well as (Hunt, 2000) study which encourages the practice of sports from an early age.

Table (8)The arithmetic mean, standard deviation, and percentage according to the objectives

\begin{tabular}{|l|l|l|l|l|}
\hline No. & Objectives area & $\begin{array}{l}\text { arithmetic } \\
\text { mean }\end{array}$ & $\begin{array}{l}\text { standard } \\
\text { deviation }\end{array}$ & percentage \\
\hline 1 & $\begin{array}{l}\text { early detection of a "promising" } \\
\text { Athletics }\end{array}$ & 3.77 & 0.49 & $\% 75.4$ \\
\hline
\end{tabular}




\begin{tabular}{|l|l|l|l|l|}
\hline 2 & $\begin{array}{l}\text { provide "promising" with physical } \\
\text { foundations and skill }\end{array}$ & 4.44 & 0.66 & $\% 88.8$ \\
\hline 3 & $\begin{array}{l}\text { provide "promising" with the Athletics } \\
\text { foundations knowledge }\end{array}$ & 3.88 & 0.75 & $\% 77.6$ \\
\hline 4 & $\begin{array}{l}\text { Activation of the participation of } \\
\text { "promising" in clubs }\end{array}$ & 3.09 & 0.85 & $\% 61.8$ \\
\hline 5 & $\begin{array}{l}\text { Selecting distinctive "promising" to } \\
\text { form the team }\end{array}$ & 2.99 & 0.58 & $\% 60.2$ \\
\hline 6 & $\begin{array}{l}\text { Educate "promising" with rules of } \\
\text { Athletics }\end{array}$ & 3.62 & 0.46 & $\% 72.4$ \\
\hline 7 & $\begin{array}{l}\text { spread the game to become the most } \\
\text { popular }\end{array}$ & 4.18 & 0.71 & $\% 83.6$ \\
\hline
\end{tabular}

Highest degree (35) lowest degree (7) $\quad \mathrm{n}=104$

Table (8) shows the statistical values for goals field, and generally the total value of the area was $(72.4 \%)$ percentage, showing that the strategy adopted a real goals that can be applied in a very high, high, and medium degree, and was found out that the most estimated paragraphs was paragraph (2), (provide "promising" with physical foundations and skill) related to the Athletics events with a $(88.8 \%)$ percentage, followed by paragraph (7), (published game to become the most popular) by $(83.6 \%)$ percentage.

The researchers explained these answers that the strategy is clear and designed to give the "promising" physical abilities and skills in athletics events, and even contribute to implant the values of love and belonging for the game to make it the most popular among practitioners and audiences and thus the application was very high. the least recognized paragraphs in order was paragraph (5), (Selecting distinctive "promising" to form the team), this is a secondary objective in the first phase and not necessarily forming a national team but also equipping them with the principles of the athletics, so it was moderately recognized, the results of this study are consistent with the study of (Al Magreebe, 1999), in the organization of the prepared strategy objectives, as well as (Smyth, 1998) study which aimed at preparing long-term plans.

Table (9)The arithmetic mean standard deviation and percentage according to the curricula and special programs

\begin{tabular}{|l|l|l|l|l|}
\hline No. & $\begin{array}{l}\text { the curricula and special programs area } \\
\text { related to the "promising, }\end{array}$ & $\begin{array}{l}\text { arithmetic } \\
\text { mean }\end{array}$ & $\begin{array}{l}\text { standard } \\
\text { deviation }\end{array}$ & percentage \\
\hline 1 & $\begin{array}{l}\text { curriculum focuses on basic Athletics } \\
\text { skills }\end{array}$ & 4.70 & 0.65 & $\% 94$ \\
\hline 2 & $\begin{array}{l}\text { the curriculum includes teaching } \\
\text { assistance in the training }\end{array}$ & 3.37 & 0.69 & $\% 67.4$ \\
\hline
\end{tabular}




\begin{tabular}{|l|l|l|l|l|}
\hline 3 & $\begin{array}{l}\text { diversifying of the curriculum } \\
\text { program, commensurate with the } \\
\text { development of "promising }\end{array}$ & 0.86 & $\% 77.2$ \\
\hline 4 & $\begin{array}{l}\text { curriculum includes programs in } \\
\text { fitness tests }\end{array}$ & 4.44 & 0.87 & $\% 88.8$ \\
\hline 5 & $\begin{array}{l}\text { specify the period and time of the } \\
\text { training unit }\end{array}$ & 3.55 & 0.82 & $\% 71$ \\
\hline 6 & $\begin{array}{l}\text { The curriculum contains the special } \\
\text { skill tests }\end{array}$ & 4.13 & 0.49 & $\% 82.6$ \\
\hline 7 & $\begin{array}{l}\text { curriculum focuses on educational and } \\
\text { health dimensions }\end{array}$ & 3.42 & 0.62 & $\% 68.4$ \\
\hline 8 & $\begin{array}{l}\text { curriculum focuses on the principles of } \\
\text { the law of Athletics }\end{array}$ & 2.35 & 0.87 & $\% 47$ \\
\hline 9 & $\begin{array}{l}\text { the formation of a Committee of } \\
\text { experts to evaluate the curriculum }\end{array}$ & 3.80 & 0.79 & $\% 76$ \\
\hline & \begin{tabular}{l} 
Public domain \\
\hline
\end{tabular} & 3.73 & 0.72 & $\% 74.6$ \\
\hline
\end{tabular}

Highest degree (45) lowest degree (9)

$\mathrm{n}=104$

Table (9) shows the statistical results of the curricula and program for "promising" the results for this domain were $(74.6 \%)$ high estimation, paragraphs were limited between very high, high, medium and low, and that most estimated paragraphs in first place was paragraph (1) (curriculum focuses on basic athletics skills) with (94\%) percentage, which is very high estimate, and least paragraphs estimated in arrangement was (8), (curriculum focuses on the principles of the law of Athletics), (47\%) percentage a little.The researchers explained that the curriculum must include basic skills in athletics, dominated by practice and application, not the theoretical side, and not focus on the law from the point of view of the study sample, because the attention is mainly on physical and skill domain, so the rating was little compared with other paragraphs, the results of this study are consistent with (Khalidi, 2003), (Keeshtah, 2004) studies, the lack of attention of "promising" special program .

Table (10)The arithmetic mean, standard deviation and percentage according to the trainer's qualification area.

\begin{tabular}{|l|l|l|l|l|}
\hline No. & trainers qualification & $\begin{array}{l}\text { arithmetic } \\
\text { mean }\end{array}$ & $\begin{array}{l}\text { standard } \\
\text { deviation }\end{array}$ & percentage \\
\hline 1 & $\begin{array}{l}\text { trainer should be acquainted with plans } \\
\text { and skills for athletics }\end{array}$ & 4.79 & 0.62 & $\% 95.8$ \\
\hline 2 & $\begin{array}{l}\text { Giving specialized courses to train the } \\
\text { "promising" }\end{array}$ & 3.81 & 0.73 & $\% 76.2$ \\
\hline 3 & $\begin{array}{l}\text { Giving a session for trainers at the } \\
\text { end of each phase }\end{array}$ & 3.39 & 0.88 & $\% 067.8$ \\
\hline 4 & \begin{tabular}{l} 
Providing the trainer with the goals of \\
\hline
\end{tabular} & 4.11 & 0.82 & $\% 82.2$ \\
\hline
\end{tabular}




\begin{tabular}{|l|l|l|l|l|}
\hline & "promising" schools & & & \\
\hline 5 & $\begin{array}{l}\text { acquainted the trainer with the goals of } \\
\text { "promising" schools }\end{array}$ & 4.22 & 0.82 & $\% 84.4$ \\
\hline 6 & $\begin{array}{l}\text { send the trainer to courses for } \\
\text { beginners }\end{array}$ & 3.58 & 0.89 & $\% 71.6$ \\
\hline 7 & $\begin{array}{l}\text { Making special workshops for the law } \\
\text { of Athletics }\end{array}$ & 3.01 & 0.59 & $\% 60.2$ \\
\hline & Public domain & 3.84 & 0.76 & $\% 76.8$ \\
\hline
\end{tabular}

Highest degree

(35) lowest degree

$\mathrm{n}=104$

Table (10) shows the statistical results of trainers qualifications in general $(76.8 \%)$ with a high degree and the estimation of the paragraphs was limited between very high, high and medium, and that most paragraphs in recognition was first paragraph (1), (trainer understanding of the basis of skills and plans) with (95.8\%) percentage, in a very high degree, followed by paragraph (2), (providing trainer of the "promising" school's with curriculum), with $(84.4 \%)$ percentage which is very high compared to other paragraphs. so trainers should be used within qualified specifications, the most important one of them is knowing the skills and plans bases the and full knowledge of the objectives of the athletics curricula for the beginners, the least estimated paragraphs was paragraph (7), (giving special workshops for trainers in Athletics law) with (60.2) percentage, moderate estimation compared with the other paragraphs in the same domain, it is not necessary for the trainer to apply law on bingers because they need to establish their skill so it is advisable not to abide by the law, so the estimation was average, the result of this study are consistent with (Taha, 2007), (Kamel, 2009) study with attention to training program and trainers when implementing the strategy.

Table (11)The arithmetic mean, standard deviation and percentage according to the area of potential and human resources

\begin{tabular}{|l|l|l|l|l|}
\hline No. & $\begin{array}{l}\text { the area of potential and human } \\
\text { resources }\end{array}$ & $\begin{array}{l}\text { arithmetic } \\
\text { mean }\end{array}$ & $\begin{array}{l}\text { standard } \\
\text { deviation }\end{array}$ & percentage \\
\hline 1 & $\begin{array}{l}\text { collaboration with School Sports } \\
\text { Federation }\end{array}$ & 3.58 & 0.82 & $\% 71.6$ \\
\hline 2 & $\begin{array}{l}\text { use the private sector to care for the } \\
\text { most "promising" schools }\end{array}$ & 3.74 & 0.85 & $\% 74.8$ \\
\hline 3 & $\begin{array}{l}\text { provide equipment to the most } \\
\text { "promising" schools }\end{array}$ & 4.61 & 0.61 & $\% 92.2$ \\
\hline 4 & $\begin{array}{l}\text { use of qualified training cadres } \\
\text { hiring highly qualified administrators }\end{array}$ & 4.00 & 0.76 & $\% 80$ \\
\hline 5 & $\begin{array}{l}\text { providing lounges to prepare } \\
\text { "promising }\end{array}$ & 4.10 & 0.83 & $\% 62.4$ \\
\hline 7 & \begin{tabular}{l} 
provide material support from IOC \\
\hline 8
\end{tabular} & 4.45 & 0.58 & $\% 89$ \\
\hline support the "promising" draft in & 4.11 & 0.48 & $\% 82.2$ \\
\hline
\end{tabular}




\begin{tabular}{|l|l|l|l|l|}
\hline & centers & & & \\
\hline 9 & $\begin{array}{l}\text { the formation of committees to find the } \\
\text { promising in Athletics }\end{array}$ & 3.59 & 0.84 & $\% 71.8$ \\
\hline 10 & $\begin{array}{l}\text { use of referees to clarify Athletics } \\
\text { principles }\end{array}$ & 2.49 & 0.89 & $\% 49.8$ \\
\hline 11 & $\begin{array}{l}\text { establishment of official tournaments } \\
\text { in the agenda of the Union }\end{array}$ & 3.88 & 0.71 & $\% 77.6$ \\
\hline 12 & Providing medical care & 3.36 & 0.62 & $\% 67.2$ \\
\hline & Public domain lowest degree (12) & 3.75 & 0.74 & $\% 75$ \\
\hline
\end{tabular}

Table (11) shows the statistical values of the potential and human resources field where the domain estimates was (75\%) which is high, the degree of the domain was confined between the very high, high, medium and low, and that most paragraphs estimation was paragraph (3), (provide equipment to the most "promising" schools) with (92.2\%) percentage which is very high from the point of view of the study sample, and the lack of equipment and material resources stops the implementation of the project, and least estimated paragraph was paragraph (10), (use of referees to clarify Athletics principles (49.8\%) which is little, researchers attribute this answer to the reason that the volunteers did not represent the real efficiencies in project implementation so the rating was little were compared with other paragraphs. The results of this study are consistent with a study of (Taha, 2007), (Hussien, 2009), the lack of material support and equipments from the official committees epically the Olympic Committee, as well as (Al-aogbee, 2007) study, the strategy encouraging the construction of sport facilities.

Table (12)The arithmetic mean, standard deviation and percentage according to the area of constraints

\begin{tabular}{|c|c|c|c|c|}
\hline No. & the area of constraints & $\begin{array}{l}\text { arithmetic } \\
\text { mean }\end{array}$ & $\begin{array}{l}\text { standard } \\
\text { deviation }\end{array}$ & percentage \\
\hline 1 & lack of clubs interest in "promising" & 4.55 & 0.73 & $\% 91$ \\
\hline 2 & $\begin{array}{l}\text { lack of stadiums and halls for Athletics } \\
\text { events }\end{array}$ & 4.04 & 0.88 & $\% 80.8$ \\
\hline 3 & $\begin{array}{l}\text { lack of interest in programs of athletics } \\
\text { school }\end{array}$ & 4.23 & 0.57 & $\% 84.6$ \\
\hline 4 & $\begin{array}{l}\text { lack of coordination between the } \\
\text { Federation and the Federation of } \\
\text { school athletics }\end{array}$ & 4.36 & 0.62 & $\% 87.2$ \\
\hline 5 & $\begin{array}{l}\text { the lack of interest of decision-makers } \\
\text { in the "promising" schools }\end{array}$ & 4.38 & 0.77 & $\% 87.6$ \\
\hline 6 & $\begin{array}{l}\text { The weakness programs to prepare } \\
\text { trainers for "promising" }\end{array}$ & 3.88 & 0.42 & $\% 77.6$ \\
\hline 7 & The weakness of financial support & 4.78 & 0.83 & $\% 95.6$ \\
\hline
\end{tabular}




\begin{tabular}{|l|l|l|l|l|}
\hline & $\begin{array}{l}\text { from official committees for } \\
\text { "promising" }\end{array}$ & & \\
\hline 8 & $\begin{array}{l}\text { the lack of media interest in } \\
\text { "promising" area }\end{array}$ & 3.83 & 0.67 & $\% 76.6$ \\
\hline & Public domain & 4.25 & 0.68 & $\% 85$ \\
\hline
\end{tabular}

Highest degree (40) $\quad$ lowest degree (8) $\quad \mathrm{n}=104$

Table (12), the statistical values of the constraints area that limit the "promising" schools project in Jordan from the point of view of the study sample, and shows that the degree of estimation is generally very high $(85 \%)$ Demonstrating the availability of multiple constraints, the most estimated constraints is paragraph (7), (weak material support from official bodies for the "promising"), in a very high percentage (59.4\%), followed paragraph (1), (lack of clubs interest in "promising"), (91\%) percentage with a very high degree.

The researcher explained that the financial aspect plays a major role in establishing the draft of the "promising" project from tools, transportation and salaries of coaches, and many other payments, and centers don't fully contribute or even fail completely in the "promising" project, so the centers suffer from lack of players with high efficiency due to the absence of a clear strategy of "promising", the least estimated paragraphs in recognition of paragraph (8), (the lack of media interest in "promising" area), with (76.6\%) percentage high degree, but in light of the other constraints it is not consider a major constraint in the implementation of "promising" project but a secondary constraint and not effective in comparison with other paragraphs, and the results of this study are consistent with the study of (Marwa, 2000) (Keeshtah, 2004), (ISSA, Radwan, 2009), insufficient financial support for the implementation of the proposed strategy.

Table (13)The arithmetic mean, standard deviation and percentage according to the area of evaluation of the "promising"

\begin{tabular}{|l|l|l|l|l|}
\hline No. & $\begin{array}{l}\text { the area of evaluation of the } \\
\text { "promising" }\end{array}$ & $\begin{array}{l}\text { arithmetic } \\
\text { mean }\end{array}$ & $\begin{array}{l}\text { standard } \\
\text { deviation }\end{array}$ & percentage \\
\hline 1 & diversity in evaluation Tools & 4.50 & 0.61 & $\% 90$ \\
\hline 2 & $\begin{array}{l}\text { specialists supervise the evaluation } \\
\text { process }\end{array}$ & 4.54 & 0.69 & $\% 90.8$ \\
\hline 3 & Special evaluation of every stage & 3.10 & 0.99 & $\% 62$ \\
\hline 4 & evaluation must be objective & 4.12 & 0.87 & $\% 82.4$ \\
\hline 5 & $\begin{array}{l}\text { follow-up "promising" at the end of } \\
\text { each phase }\end{array}$ & 3.36 & 0.78 & $\% 67.2$ \\
\hline 6 & checking the educational materials & 4.27 & 0.59 & $\% 85.4$ \\
\hline & Public domain & 3.98 & 0.75 & $\% 79.6$ \\
\hline
\end{tabular}

Highest degree(30)

lowest degree (6)

$\mathrm{n}=104$ 


\section{MInstitute Macrothink $_{\text {Int }}^{\text {Intis }}$}

Table (13) shows the statistical result for the evaluation area, the result for this area in general was $(76.6 \%)$ with a high estimation, and that the highes estimation paragraph was paragraph (2) (specialists supervise the evaluation process, and it percentage was (\%90.8) with a very high estimation, to identify the extent of the stratigy there must be speiclaists in evauating the curriculum, trainers, test and tools to reach the goal under a sound scientist basis, and the least estimated paragraphs was (3) (Special evaluation of every stage ) with (62\%) and a moderate degree compared with other paragraphs, the researcher explain this by saying that the nature of this stage does not need a stage evaluation, but a final evaluation, and we need to bring children, and if the child feel in a short period that he is failing he might stop practicing the game, and that the sound strategic building leads to good results especially if it area representing the goals are applied, the constrains are known before, the human potentials and resources are prepared, the trainers are qualified, the curriculum and foundation of choosing have been identified, in this final stage and the evaluation is done, in the light of these areas and its result this strategy could be adopted to establish a school for the "promising" in Jordan, the results of this study is consistence with the study of (Almagrabee,1999), (Sa'adah, 2006) in the area of evauation.

Question 2: are there statistical differences in the proposed strategy depending on study variables (gender, practical experiences, qualifications and experience)?

Table (14)Arithmetic averages, standard deviations and the (t) value depending on the gender variable

\begin{tabular}{|c|c|c|c|c|c|}
\hline Variables & $\begin{array}{l}\text { Male } \\
\text { Female }\end{array}$ & $\begin{array}{l}\text { arithmetic } \\
\text { mean }\end{array}$ & $\begin{array}{l}\text { standard } \\
\text { deviation }\end{array}$ & $\mathrm{t}$ value & $\begin{array}{l}\text { indication } \\
\text { level }\end{array}$ \\
\hline \multirow{2}{*}{$\begin{array}{l}\text { the } \\
\text { foundations } \\
\text { "promising" } \\
\text { selection }\end{array}$} & Male & 3.77 & 0.79 & \multirow[t]{2}{*}{0.23} & \multirow{2}{*}{$\begin{array}{l}\text { Not } \\
\text { statistically } \\
\text { significance }\end{array}$} \\
\hline & Female & 3.81 & 0.69 & & \\
\hline \multirow[t]{2}{*}{ Goals axis } & Male & 3.65 & 0.81 & \multirow[t]{2}{*}{0.18} & \multirow{2}{*}{$\begin{array}{l}\text { Not } \\
\text { statistically } \\
\text { significance }\end{array}$} \\
\hline & Female & 3.60 & 0.75 & & \\
\hline \multirow{2}{*}{$\begin{array}{l}\text { curriculum } \\
\text { and special } \\
\text { programs } \\
\text { Axis for } \\
\text { "promising" }\end{array}$} & Male & 3.89 & 0.79 & \multirow[t]{2}{*}{0.69} & \multirow{2}{*}{$\begin{array}{l}\text { Not } \\
\text { statistically } \\
\text { significance }\end{array}$} \\
\hline & Female & 3.89 & 0.76 & & \\
\hline \multirow{2}{*}{$\begin{array}{l}\text { Referees } \\
\text { qualification } \\
\text { axis }\end{array}$} & Male & 3.99 & 0.84 & \multirow[t]{2}{*}{0.31} & \multirow{2}{*}{$\begin{array}{l}\text { Not } \\
\text { statistically } \\
\text { significance }\end{array}$} \\
\hline & Female & 3.86 & 0.70 & & \\
\hline
\end{tabular}




\begin{tabular}{|c|c|c|c|c|c|}
\hline \multirow{2}{*}{$\begin{array}{l}\text { Human } \\
\text { resources axis }\end{array}$} & Male & 3.56 & 0.73 & \multirow[t]{2}{*}{0.42} & \multirow{2}{*}{$\begin{array}{l}\text { Not } \\
\text { statistically } \\
\text { significance }\end{array}$} \\
\hline & Female & 3.55 & 0.72 & & \\
\hline \multirow{2}{*}{$\begin{array}{l}\text { Constraints } \\
\text { axis }\end{array}$} & Male & 3.37 & 0.74 & \multirow[t]{2}{*}{0.58} & \multirow{2}{*}{$\begin{array}{l}\text { Not } \\
\text { statistically } \\
\text { significance }\end{array}$} \\
\hline & Female & 3.46 & 0.61 & & \\
\hline \multirow{2}{*}{$\begin{array}{l}\text { Evaluation } \\
\text { axis }\end{array}$} & Male & 4.01 & 0.77 & \multirow[t]{2}{*}{0.52} & \multirow{2}{*}{$\begin{array}{l}\text { Not } \\
\text { statistically } \\
\text { significance }\end{array}$} \\
\hline & Female & 3.91 & 0.71 & & \\
\hline
\end{tabular}

$\mathrm{t}$ value at the indication level $(0.05>=\&)=1.92$

Table (14) shows the statistical results for the gender variable, the results show that there are no statistically differences for calculated $t$ value in comparison with the indexed $t$ value, in all areas of the strategy, where the calculated $t$ value was limited between (0.18-0.69). Researcher explains these estimates as being convergent between male and female in the areas of strategy and its paragraphs, and can be applied to establish the "promising" schools of the Jordanian Federation of athletics; these results are consistent with (Smyth, 1998) study

Table (15)Analysis of administrative variance depending on the variable practical experience

\begin{tabular}{|c|c|c|c|c|c|}
\hline Areas & The group & $\begin{array}{l}\text { Squares } \\
\text { sum }\end{array}$ & $\begin{array}{l}\text { degree of } \\
\text { freedom }\end{array}$ & $\begin{array}{l}\text { Squares } \\
\text { average }\end{array}$ & F value \\
\hline \multirow{3}{*}{$\begin{array}{l}\text { the foundations of } \\
\text { "promising" } \\
\text { selection area }\end{array}$} & Between groups & 18,10 & 2 & 8,45 & \multirow[t]{3}{*}{15,40} \\
\hline & Inside groups & 60,48 & 101 & 0,55 & \\
\hline & Total & 78.58 & 103 & & \\
\hline \multirow[t]{3}{*}{ Goals area } & Between groups & 21,30 & 2 & 10,17 & \multirow[t]{3}{*}{12,78} \\
\hline & Inside groups & 87,60 & 101 & 0,79 & \\
\hline & Total & 108.90 & 103 & & \\
\hline \multirow{3}{*}{\begin{tabular}{lr}
\multicolumn{2}{c}{ curriculum and } \\
special programs \\
area \\
"promising"
\end{tabular}} & Between groups & 25,95 & 2 & 12,39 & \multirow[t]{3}{*}{20,76} \\
\hline & Inside groups & 65,32 & 101 & 0,58 & \\
\hline & Total & 91.27 & 103 & & \\
\hline \multirow{3}{*}{$\begin{array}{l}\text { Referees } \\
\text { qualification area }\end{array}$} & Between groups & 32,59 & 2 & 15,79 & \multirow[t]{3}{*}{23,18} \\
\hline & Inside groups & 71,95 & 101 & 0,67 & \\
\hline & Total & 104.54 & 103 & & \\
\hline \multirow{3}{*}{$\begin{array}{l}\text { Human resources } \\
\text { and potential area }\end{array}$} & Between groups & 20,88 & 2 & 9,92 & \multirow[t]{3}{*}{12,90} \\
\hline & Inside groups & 83,93 & 101 & 0,78 & \\
\hline & Total & 104.81 & 103 & & \\
\hline
\end{tabular}




\begin{tabular}{|l|l|l|l|l|l|}
\hline \multirow{3}{*}{$\begin{array}{l}\text { Constraints } \\
\text { area }\end{array}$} & Between groups & 34,89 & 2 & 16,97 & \multirow{2}{*}{18,67} \\
\cline { 2 - 5 } & Inside groups & 74.95 & 101 & 0,90 & \\
\cline { 2 - 5 } & Total & 109.84 & 103 & & \\
\hline \multirow{4}{*}{ Evaluation area } & Between groups & 37,51 & 2 & 18,22 & \multirow{2}{*}{22,42} \\
\cline { 2 - 5 } & Inside groups & 85,30 & 101 & 0,89 & \\
\cline { 2 - 5 } & Total & 122.81 & 103 & & \\
\hline
\end{tabular}

Tabular $\mathrm{f}$ value at the indication level $(0.05>\mathrm{a})=3.05$

Table (15) refers to the statistical values depending on the practical experiences variable and show that all areas statistically function as calculated $\mathrm{f}$ value for the area of selection was (15.40), field goals (12.78), curricula and program (20.76), and Referees qualification (23.18) potential (12.90), constraints (18.67) and evaluation (22.42), compared to the tabular f value at the indication level $((0.05>a)=3.05)$, therefore arithmetic averages must be found the and identify in favor of arithmetic means differences according to Scientific expertise variable, looking at the statistical values using analysis of variance, the calculated $f$ value is statistically differences depending on the variable practical experiences (Administrator, coach and referee).

Table (16)Significant differences between the arithmetic means depending on the experience variable

\begin{tabular}{|c|c|c|c|c|c|c|c|}
\hline \multirow[b]{2}{*}{ Area } & \multirow[b]{2}{*}{$\begin{array}{l}\text { Practical } \\
\text { experience }\end{array}$} & \multirow[b]{2}{*}{$\begin{array}{l}\text { Arithmeti } \\
\text { c mean }\end{array}$} & \multirow[b]{2}{*}{$\begin{array}{l}\text { Standard } \\
\text { deviation }\end{array}$} & \multicolumn{4}{|c|}{ Differences between groups } \\
\hline & & & & $\begin{array}{l}\text { Administrators } \\
\mathrm{N}=41\end{array}$ & $\begin{array}{l}\text { Trainer } \\
\mathrm{N}=38\end{array}$ & $\begin{array}{l}\text { Referees } \\
\mathrm{N}=25\end{array}$ & $\begin{array}{l}\text { significant } \\
\text { For the } \\
\text { favor of }\end{array}$ \\
\hline \multirow{3}{*}{$\begin{array}{l}\text { the } \\
\text { foundations } \\
\text { of } \\
\text { "promising" } \\
\text { selection } \\
\text { area }\end{array}$} & $\begin{array}{l}\text { Administr } \\
\text { ators }\end{array}$ & 3.83 & 0.75 & - & 0.22 & 0.18 & $\begin{array}{l}\text { Trainer, } \\
\text { Administr } \\
\text { ator }\end{array}$ \\
\hline & trainers & 4.08 & 0.64 & - & - & 0.41 & Trainer \\
\hline & Referees & 3.63 & 0.72 & - & - & - & - \\
\hline \multirow[t]{3}{*}{ Goals area } & $\begin{array}{l}\text { Administr } \\
\text { ators }\end{array}$ & 4.28 & 0.79 & - & 0.84 & 1.09 & $\begin{array}{l}\text { Administr } \\
\text { ator }\end{array}$ \\
\hline & trainers & 3.39 & 0.57 & - & - & 0.21 & Trainer \\
\hline & Referees & 3.12 & 0.77 & - & - & - & - \\
\hline \multirow{3}{*}{$\begin{array}{l}\text { curriculum } \\
\text { and special } \\
\text { programs } \\
\text { area for } \\
\text { "promising" }\end{array}$} & $\begin{array}{l}\text { Administr } \\
\text { ators }\end{array}$ & 4.09 & 0.70 & - & 0.48 & 0.59 & $\begin{array}{l}\text { Administr } \\
\text { ator }\end{array}$ \\
\hline & trainers & 3.55 & 0.71 & - & - & 0.11 & Trainer \\
\hline & Referees & 3.46 & 0.69 & - & - & - & - \\
\hline $\begin{array}{l}\text { Referees } \\
\text { qualification }\end{array}$ & $\begin{array}{l}\text { Administr } \\
\text { ators }\end{array}$ & 3.44 & 0.86 & - & 0.68 & 0.31 & $\begin{array}{l}\text { Trainer, } \\
\text { referee }\end{array}$ \\
\hline
\end{tabular}




\begin{tabular}{|c|c|c|c|c|c|c|c|}
\hline \multirow[t]{2}{*}{ area } & trainers & 4.18 & 0.76 & - & - & 0.68 & Trainer \\
\hline & Referees & 3.77 & 0.85 & - & - & - & - \\
\hline \multirow{3}{*}{$\begin{array}{l}\text { Human } \\
\text { resources } \\
\text { and } \\
\text { potential } \\
\text { area }\end{array}$} & $\begin{array}{l}\text { Administr } \\
\text { ators }\end{array}$ & 3.11 & 0.89 & - & 0.57 & 0.18 & $\begin{array}{l}\text { Trainer, } \\
\text { referee }\end{array}$ \\
\hline & trainers & 3.74 & 0.84 & - & - & 0.32 & Trainer \\
\hline & Referees & 3.27 & 0.74 & - & - & - & - \\
\hline \multirow{3}{*}{$\begin{array}{l}\text { Constraints } \\
\text { area }\end{array}$} & $\begin{array}{l}\text { Administr } \\
\text { ators }\end{array}$ & 3.12 & 0.88 & - & 0.79 & 0.20 & $\begin{array}{l}\text { Trainer, } \\
\text { referee }\end{array}$ \\
\hline & trainers & 3.99 & 0.78 & - & - & 0.58 & Trainer \\
\hline & Referees & 3.37 & 0.71 & - & - & - & - \\
\hline \multirow{3}{*}{$\begin{array}{l}\text { Evaluation } \\
\text { area }\end{array}$} & $\begin{array}{l}\text { Administr } \\
\text { ators }\end{array}$ & 4.25 & 0.57 & - & 0.37 & 0.49 & $\begin{array}{l}\text { Administr } \\
\text { ator }\end{array}$ \\
\hline & trainers & 3.74 & 0.69 & - & - & 0.10 & Trainer \\
\hline & Referees & 3.66 & 0.82 & - & - & - & - \\
\hline
\end{tabular}

Table (16) shows the differences between the arithmetic means depending on the experience variable, the arithmetic averages indicate that the foundations for choosing the "promising" for the trainer favor was (0.22), and (0.41) compared to administrative and referee, it was also found that the average differences according to goals $(0.84),(1.09)$ for the favor of the administrators, compared with the trainer and referee, in the area of curriculum the differences suggest that arithmetic means for administrative (0.48), and (0.59) compared with the trainer and referee, as well as trainers qualification arithmetic means differences in favor of trainer (0.68), (0.68), compared with the administrative and referee. In the area of potential for trainer (0.57), and (0.32), for trainer compared with the administrative and referee, and in the area of constraints arithmetic means differences was for trainer (0.79), and (0.58), compared with the administrative and referee, and in the area of evaluation differences suggest arithmetic means for administrative (0.37), and (0.49), compared with the trainer and referee.

It was found that there were statistically significant differences in favor of administrator variable in the objective, curricula, programs and evaluation areas, and the result is that administrators have longer experience in curriculum preparation, goals, evaluation, compared with referees and trainers, and in the area of constraints, human resources potential and trainers field differences appeared for trainer favor compared with the administrative and referee, and the result is that the trainer is closer to the field of management than the administrator and referee in the process of training and knowledge of requirements and also needs to be qualified by experts in the field of training of the "promising", the results of this study are consistent with a study of (Sa'adah, 2006), that there is a positive relationship between the years of experience and building the strategies of sports federations.

Table (17)Arithmetic averages and standard deviations depending on the degree variable 


\begin{tabular}{|c|c|c|c|c|c|c|c|}
\hline \multirow{2}{*}{ No. } & \multirow{2}{*}{ Areas } & \multicolumn{2}{|c|}{$\begin{array}{l}\text { Higher degrees } \\
\mathrm{N}=18\end{array}$} & \multicolumn{2}{|l|}{$\begin{array}{l}\text { Bachelor } \\
\mathrm{N}=28\end{array}$} & \multicolumn{2}{|c|}{$\begin{array}{l}\text { Diploma and less } \mathrm{N}= \\
58\end{array}$} \\
\hline & & $\begin{array}{l}\text { Arithmetic } \\
\text { mean }\end{array}$ & $\begin{array}{l}\text { Standard } \\
\text { deviation }\end{array}$ & $\begin{array}{l}\text { Arithmetic } \\
\text { mean }\end{array}$ & $\begin{array}{l}\text { Standard } \\
\text { deviation }\end{array}$ & $\begin{array}{l}\text { Arithmetic } \\
\text { mean }\end{array}$ & $\begin{array}{l}\text { Standard } \\
\text { deviation }\end{array}$ \\
\hline 1 & $\begin{array}{l}\text { the } \\
\text { foundations } \\
\text { of } \\
\text { "promising" } \\
\text { selection } \\
\text { area }\end{array}$ & 4,00 & 0,80 & 3,62 & 0,70 & 3,60 & 0,68 \\
\hline 2. & Goals area & 3,58 & 0,83 & 3,59 & 0,70 & 3,45 & 0,58 \\
\hline 3. & $\begin{array}{l}\text { curriculum } \\
\text { and special } \\
\text { programs } \\
\text { area for } \\
\text { "promising" }\end{array}$ & 3,99 & 0,90 & 3,86 & 0,58 & 3,66 & 0,77 \\
\hline 4. & $\begin{array}{l}\text { Referees } \\
\text { qualification } \\
\text { area }\end{array}$ & 3,79 & 0,72 & 3,87 & 0,61 & 3,77 & 0,69 \\
\hline 5 & $\begin{array}{l}\text { Human } \\
\text { resources } \\
\text { and potential } \\
\text { area }\end{array}$ & 3,69 & 0,81 & 3,59 & 0,68 & 3,48 & 0,61 \\
\hline 6 & $\begin{array}{l}\text { Constraints } \\
\text { area }\end{array}$ & 3,76 & 0,67 & 3,89 & 0,83 & 3,60 & 0,79 \\
\hline 7 & $\begin{array}{l}\text { Evaluation } \\
\text { area }\end{array}$ & 3,90 & 0,89 & 3,81 & 91,0 & 3,70 & 0,81 \\
\hline
\end{tabular}

Table (18)Analysis of one way Anova variance according to degree variable

\begin{tabular}{|l|l|l|l|l|l|}
\hline Areas & The group & $\begin{array}{l}\text { Squares } \\
\text { sum }\end{array}$ & $\begin{array}{l}\text { degree of } \\
\text { freedom }\end{array}$ & $\begin{array}{l}\text { Squares } \\
\text { average }\end{array}$ & F value \\
\hline \multirow{2}{*}{$\begin{array}{l}\text { the foundations of } \\
\text { "promising" } \\
\text { selection area }\end{array}$} & Between groups & 1,66 & 2 & 0,83 & \multirow{2}{*}{0,84} \\
\cline { 2 - 5 } & Inside groups & 102,41 & 101 & 0,98 & \\
\cline { 2 - 5 } Goals area & Total & 104.07 & 103 & & \multirow{2}{*}{1,70} \\
\cline { 2 - 5 } & Between groups & 3,39 & 2 & 1,72 & \\
\cline { 2 - 5 } & Inside groups & 105,32 & 101 & 1,01 & \\
\cline { 2 - 5 } & Total & 108.71 & 103 & & \\
\hline
\end{tabular}




\begin{tabular}{|c|c|c|c|c|c|}
\hline \multirow{3}{*}{$\begin{array}{l}\text { curriculum and } \\
\text { special programs } \\
\text { area } \\
\text { "promising" }\end{array}$} & Between groups & 3,45 & 2 & 1,72 & \multirow[t]{3}{*}{1,68} \\
\hline & Inside groups & 123,35 & 101 & 1,18 & \\
\hline & Total & 126.80 & 103 & & \\
\hline \multirow{3}{*}{$\begin{array}{l}\text { Referees } \\
\text { qualification area }\end{array}$} & Between groups & 2,04 & 2 & 1,02 & \multirow[t]{3}{*}{1,00} \\
\hline & Inside groups & 105,21 & 101 & 1,01 & \\
\hline & Total & 107.25 & 103 & & \\
\hline \multirow{3}{*}{$\begin{array}{l}\text { Human resources } \\
\text { and potential area }\end{array}$} & Between groups & 1,42 & 2 & 0,71 & \multirow[t]{3}{*}{0,74} \\
\hline & Inside groups & 99,56 & 101 & 0,95 & \\
\hline & Total & 100.98 & 103 & & \\
\hline \multirow{3}{*}{$\begin{array}{l}\text { Constraints } \\
\text { area }\end{array}$} & Between groups & 4,21 & 2 & 2,10 & \multirow[t]{3}{*}{1,81} \\
\hline & Inside groups & 121,42 & 101 & 1,16 & \\
\hline & Total & 125.63 & 103 & & \\
\hline \multirow{3}{*}{ Evaluation area } & Between groups & 2.95 & 2 & 1.47 & \multirow[t]{3}{*}{1.42} \\
\hline & Inside groups & 108.12 & 101 & 1.03 & \\
\hline & Total & 111.07 & 104 & & \\
\hline
\end{tabular}

Tabular $f$ value at the level of significance $(\alpha<0.05)=3.05$

Table (17) shows the arithmetic means and standard deviations according to a degree variable, table (18) as well shows the statistical values using analysis of variance, calculated $\mathrm{f}$ value showed that there were no statistical differences in comparison with the indexed $\mathrm{f}$ value according to the degree variable, the reason is that all estimates on strategic areas were convergent in the views of individuals with academic qualification variable and it could be applied, and the results of this study differs from the study of (Sa'adah, 2006), that the qualification plays a big role in building the strategies and decision-making.

Table (19)Arithmetic averages and standard deviations depending on the years of experience variable

\begin{tabular}{|l|l|l|l|l|l|l|l|}
\hline \multirow{2}{*}{ No. } & \multirow{2}{*}{$\begin{array}{l}\text { Areas } \\
\text { Nore than 5 years }\end{array}$} & \multicolumn{2}{l|}{$\begin{array}{l}\text { Between 5-3 years } \\
\mathrm{N}=40\end{array}$} & \multicolumn{2}{l|}{$\begin{array}{l}\text { Less than 3 years } \\
\mathrm{N}=31\end{array}$} \\
\cline { 2 - 7 } & $\begin{array}{l}\text { Arithmetic } \\
\text { mean }\end{array}$ & $\begin{array}{l}\text { Standard } \\
\text { deviation }\end{array}$ & $\begin{array}{l}\text { Arithmetic } \\
\text { mean }\end{array}$ & $\begin{array}{l}\text { Standard } \\
\text { deviation }\end{array}$ & $\begin{array}{l}\text { Arithmetic } \\
\text { mean }\end{array}$ & $\begin{array}{l}\text { Standard } \\
\text { deviation }\end{array}$ \\
\hline 1 & $\begin{array}{l}\text { the } \\
\text { foundations } \\
\text { of } \\
\text { "promising" } \\
\text { selection } \\
\text { area }\end{array}$ & 4,04 & 0,91 & 3,79 & 0,85 & 3,48 & 0,50 \\
\hline 2. & Goals area & 3,89 & 0,91 & 3,81 & 0,71 & 3,80 & 0,81 \\
\hline
\end{tabular}




\begin{tabular}{|l|l|l|l|l|l|l|l|}
\hline 3. & $\begin{array}{l}\text { curriculum } \\
\text { and special } \\
\text { programs } \\
\text { area for } \\
\text { "promising" }\end{array}$ & 3,93 & 0,92 & 3,91 & 0,83 & 3,28 & 0,59 \\
\hline 4. & $\begin{array}{l}\text { Referees } \\
\text { qualification } \\
\text { area }\end{array}$ & 4,01 & 0,87 & 3,61 & 0,78 & 3,61 & 0,75 \\
\hline 5 & $\begin{array}{l}\text { Human } \\
\text { resources } \\
\text { and potential } \\
\text { area }\end{array}$ & 3,69 & 0,90 & 3,86 & 0,62 & 3,79 & 0,72 \\
\hline 6 & $\begin{array}{l}\text { Constraints } \\
\text { area }\end{array}$ & 3,77 & 0,52 & 3,81 & 0,91 & 3,68 & 0,61 \\
\hline 7 & $\begin{array}{l}\text { Evaluation } \\
\text { area }\end{array}$ & 3,86 & 0,87 & 3,82 & 0,84 & 3,61 & 0,60 \\
\hline
\end{tabular}

Table (20)Analysis of variance depending on the years of experience variable

\begin{tabular}{|c|c|c|c|c|c|}
\hline Areas & The group & $\begin{array}{l}\text { Squares } \\
\text { sum }\end{array}$ & $\begin{array}{l}\text { degree of } \\
\text { freedom }\end{array}$ & $\begin{array}{l}\text { Squares } \\
\text { average }\end{array}$ & F value \\
\hline \multirow{3}{*}{$\begin{array}{l}\text { the foundations of } \\
\text { "promising" } \\
\text { selection area }\end{array}$} & Between groups & 1,99 & 2 & 0,99 & \multirow[t]{3}{*}{0,98} \\
\hline & Inside groups & 105,44 & 101 & 1,01 & \\
\hline & Total & 107,43 & 103 & & \\
\hline \multirow[t]{3}{*}{ Goals area } & Between groups & 3,05 & 2 & 1,52 & \multirow[t]{3}{*}{1,36} \\
\hline & Inside groups & 115,56 & 101 & 1,11 & \\
\hline & Total & 118,61 & 103 & & \\
\hline \multirow{3}{*}{\begin{tabular}{l}
\multicolumn{2}{c}{ curriculum and } \\
special programs \\
area \\
"promising"
\end{tabular}} & Between groups & 1,45 & 2 & 0,72 & \multirow[t]{3}{*}{0,62} \\
\hline & Inside groups & 119,67 & 101 & 1,15 & \\
\hline & Total & 121,12 & 103 & & \\
\hline \multirow{3}{*}{$\begin{array}{l}\text { Referees } \\
\text { qualification area }\end{array}$} & Between groups & 2,51 & 2 & 1,25 & \multirow[t]{3}{*}{1.05} \\
\hline & Inside groups & 124,21 & 101 & 1,19 & \\
\hline & Total & 126,72 & 103 & & \\
\hline \multirow{3}{*}{$\begin{array}{l}\text { Human resources } \\
\text { and potential area }\end{array}$} & Between groups & 1,93 & 2 & 0,96 & \multirow[t]{3}{*}{0,73} \\
\hline & Inside groups & 136,21 & 101 & 1,30 & \\
\hline & Total & 138,14 & 103 & & \\
\hline \multirow{2}{*}{$\begin{array}{l}\text { Constraints } \\
\text { area }\end{array}$} & Between groups & 2,10 & 2 & 1,05 & \multirow[t]{2}{*}{1,05} \\
\hline & Inside groups & 104,57 & 101 & 1,00 & \\
\hline
\end{tabular}




\begin{tabular}{|l|l|l|l|l|l|}
\hline & Total & 106,67 & 103 & & \\
\hline \multirow{4}{*}{ Evaluation area } & Between groups & 2,78 & 2 & 1,93 & \multirow{2}{*}{1,78} \\
\cline { 2 - 5 } & Inside groups & 112,89 & 101 & 1,08 & \\
\cline { 2 - 5 } & Total & 115,67 & 103 & & \\
\hline
\end{tabular}

The tabular $f$ value at the level of significance $(\alpha \leq 0.05)=3.05$

The table (19) shows arithmetic means and standard deviations, depending on years of experience variable, and table (20) shows that statistical values using one way analysis of variance depending on the years of experience variable, and the calculated $f$ value that there is no statistical differences in comparison with the indexed $f$ value.

The researchers explained this result that individuals classified as individuals with years of experience, have give the too close answers, which shows the identical views on the of strategic application of the "promising" Athletics schools foundation in Jordan, previous studies did not address years of experience variable to compare the results with previous studies.

\section{Conclusions}

In the light of the results the following conclusions were reached:-

1. Administrators and trainers are the most understanding individuals of the importance of application of strategic areas in comparison with the referees.

2. the convergence of views on the application of strategic areas to establish "promising" athletics schools in Jordan

3. Convergence of views depending on the qualification variable in the application of all areas of the strategy to establish "promising" schools in athletics in Jordan.

4. Convergence of views depending on years of experience variable in the application of the all areas of the strategy to establish "promising" schools in athletics in Jordan.

5. the need for a strategy to establish "promising" schools in athletics in Jordan based on scientific grounds include (foundations of "promising" selection, objectives, curriculum and special programs, trainers qualifying, facilities and human resources and evaluation) according to the gender variable.

\section{Recommendations}

In the light of the reached conclusions the following recommendations have been reached:

1. Benefit from the expertise of managers and trainers in the application of strategic areas to establish "promising" schools in athletics.

2. The Jordan Athletics Federation should adopt this strategy to establish "promising" schools.

3. Address the constraints which limit the "promising" project of the Jordanian Federation of athletics.

4. similar studies should be done to develop the proposed strategies and address the constraints that limit the "promising" project for unions of the Jordan Olympic Committee 


\section{References:}

- Abu Al-Haija, Sherine Ahmed (2006), the extent of the application of total quality management in colleges of physical education in Jordanian universities, doctoral thesis, unpublished, University of Jordan, Oman, Jordan, p. 22-54.

- Abu Halima,-Hosni Fa'ek (2004). Talk in sports management, (1st floor), Wael publishing, Oman, pp. 66-67.

- al-Khalidi, Ayed Mohammad. (2003), the problems facing the sport planning from the viewpoint of sports associations in the Country of Kuwait, Master thesis (unpublished), University of Jordan, Oman, Jordan, p. 78-110

- Al-Khatib, Saleh (2003), strategic planning and institutional performance, master of the University of Jordan, Amman, Jordan, p. 29.

- Al-Rakad, Ra'ed and Al-Mansur, Yasser (2011), the reality of total quality management standards in the sports federations from the point of view of the heads of sports federations, Mutah research and studies, a series of human and social sciences, vol. 26, no. 1, pp. 11-40.

- AlZogbee, Saleh. (2007), building sports strategy for everybody in the Balqa University, unpublished $\mathrm{PhD}$ thesis, Faculty of physical education, University of Jordan, pp. 11-15

- AlGalibi, Tahir, and Idris Muhammad (2007). Strategic management, systematic and integrated perspective, Wael publishing, Amman, p. 59.

- Al Magreebe, Abed alftah. (1999), strategic management to meet the challenges of the twenty-first century, Arabic, Egypt Nile Group.

- Nagar, Faiz (2001), strategic planning in small organizations, Master thesis (unpublished), Yarmouk University, Irbid, Jordan, pp. 28-67.

- Hussain, Abed Alsalam. (2007). Constraints facing the referee of volleyball in Jordan, the first scientific conference, the role of the colleges and departments of physical education institutes in developing sport Arabic, vol. II, Amman, Jordan, pp. 266-287.

- Sa'adah, Nayef (2006). Strategic thinking of leaders in Jordanian sports federations and its relationship to decision-making, unpublished $\mathrm{PhD}$ thesis, University of Jordan, Amman, Jordan, p. 27-80.

- Taha, Manal (2007), a strategy for the development of volleyball in Jordan, unpublished $\mathrm{PhD}$ thesis, Faculty of physical education, University of Jordan, Jordan, pp. 15-80.

- Aboee, Zaid (2006), strategic management, Amman: Treasure House of knowledge, p. 21-22.

- Issa, Suha Adeeb, Rizwan Mohamed (2009), strategic planning and constraints in the sports federations (comparative study between Jordan and Yemen). Math 6th scientific conference entitled sport and his orientalisms look towards the development of the third millennium, the College of physical education, University of Jordan, pp. 159-185.

- Keeshtah, Amor (2004), strategic planning for sports federations for the tournaments, Alexandria, Egypt, p. 25-26.

- Kamel, Khaled (2009), new strategies for planning the training of beginners in the sport of swimming, the third Scientific Conference towards a future vision for comprehensive physical culture, Yarmouk University, Jordan, pp. 73-90. 


\section{Macrothink}

- Marwa, Mohamad. (2000), a strategy to increase the number of practitioners of volleyball in Helwan district, unpublished ma thesis, University of Helwan, Egypt, p. 18-88.

Besanko,D. Dranvoe ,D. and Shanley,M.(2000).Economics of strategy, second edition john wileg and sons inc.

Bonn,I. Park,H.(1995).The management of sport, its foundation sure studies Philadelphia pansy, Ivanio,p 11.

Glaister,K.and Flashow,J.(1999). Straticgic planning still going strong, long range planing ,32 1:107-116.

Hunt,R. (2000).A Sport by future for all the government strategy for sport decision and actions required cultural series executive , England.

Joel, D.(2003). Volleyball fundamentals. Human kinetics.USA. p 11-30.

Kriemadis, Athanasios. (1997), Strategic planning in higher education athletic departments. International Journal of Educational Management, 238-247.

Robsan ,W.(1997).Strategic management and information systems :An integrated approach, p38.

Smith,T.(1998). Strategies for developing middle ,by developing centers ,Canda, p42 